\title{
BENCHMARKING OF POTATO PESTICIDE USE IN CANTERBURY
}

\author{
R.F. VAN TOOR, S.L.H. VILJANEN-ROLLINSON and D.A.J. TEULON
}

\author{
Crop \& Food Research, Private Bag 4704, Christchurch, New Zealand
}

Corresponding author:vantoorr@crop.cri.nz.

\begin{abstract}
Pesticides for weed, insect and disease control in potatoes in Canterbury were assessed via spray diaries tabulated using SprayView Analyst (HortPlus). Spray diaries for 17-30 seed crops in six growing seasons (1999-2006) and 71-100 process crops in four growing seasons (2003-2007), gave data for $13 \%$ of the area grown for seed for use by process factories and $28 \%$ of the area grown for process potatoes in New Zealand. In the most recent growing seasons of the survey, seed crops were mostly treated with metribuzin herbicide, pencycuron, mancozeb/metalaxyl-M, azoxystrobin and propineb fungicides, and methamidophos, pymetrozine and pirimicarb insecticides. Process crops had mostly cyanazine, glyphosate, linuron and metribuzin herbicides, and pencycuron azoxystrobin, chlorothalonil, copper hydroxide, fluazinam and mancozeb/metalaxyl-M fungicides. Weeds, pathogens of early and late blight, and aphids were presumed the primary pest targets. Pesticide resistance strategies were followed in later years in half of seed crops and most process crops.
\end{abstract}

Keywords: potato, aphid, pesticide use, spray practices, grower survey, spray diaries, SprayViewAnalyst.

\section{INTRODUCTION}

Benchmarking of industry agrichemical use has been important in the successful development and implementation of integrated pest management programmes. In the fruit sector, for example, assessments of individual spray diaries have led to identification of high or unnecessary use, improved timing of applications and identification of inappropriate product choices, particularly relating to resistance management strategies (Manktelow et al.2005). Benefits that may come from recording and analysing pesticide use data include identifying the proportion of an industry sector using best practice for pest control, predicting future pest resistance issues or non-target impacts on beneficial insects, grower education, improved market access, understanding the reasons for pest outbreaks, responses to invasive organisms, formulating biosecurity policy and planning for the introduction of new pesticides. Analysis of pesticide use is especially useful when linked to analysis of any pest scouting or disease forecasting, as well as pest, disease and weed control outcomes achieved as a result of the use pattern.

In New Zealand, as indicated in the Novachem agrichemical manual (Anon. 2008), fungicides are applied to potatoes to control primarily pathogens of early blight (Alternaria solani) and late blight (Phytophthora infestans); insecticides are used to control potato tuber moth (Phthorimaea operculella) and several species of virus-transmitting aphids, especially the green peach aphid (Myzus persicae) (Stufkens \& Teulon 2001); and herbicides are used to control weeds for removal of plant competitors and hosts of viruliferous aphids. Weed competition, and the requirement to keep potatoes free from fungal and viral diseases, necessitates a thorough and exacting pest control programme often resulting in multiple pesticide applications. Pesticide control programmes that rely on the multiple use of the same or related pesticides can lead to pesticide resistance in the 
absence of pesticide resistance management strategies (Martin et al. 2005). Resistance to metalaxyl (including metalaxyl-M) in Phytophthora infestans was recorded in New Zealand in the 1980s (Hartill et al. 1983), and is common in countries with both A1 and A2 mating types (Lehtinen et al. 2008). Resistance to strobilurin fungicides in Alternaria solani has been reported in the US (Rosenzweig et al. 2008), although not yet in New Zealand. Insecticide resistance to aphids that colonise potatoes has already been documented in New Zealand (Cameron \& Walker 1988; Fellowes \& Fergusson 1994; Martin \& Workman 1997; van Toor et al. 2008).

In this paper pesticide use patterns in Canterbury, New Zealand, are outlined for potato seed crops (grown for the process producers) and process crops. Spray use was established through examination of grower spray diaries. These data provide a benchmark for future analysis of pesticide use in potatoes in New Zealand. Pesticide use is discussed in relation to sustainable pest management.

\section{METHODS}

Spray diaries from Canterbury potato growers (permission from each obtained) were accessed through Alex McDonald Merchants, Darfield, Canterbury, for seed crops, and McCain Foods Ltd, Washdyke, South Canterbury, for process crops. Spray data from seed crops (6-11 growers representing 17-30 crops) and process crops (11 growers representing 71-100 crops) were obtained and examined. The seed crops were grown for propagation from cut seed for process production, in contrast to propagation from whole seed that is grown for the fresh varietal market. Crops are defined as comprising a single potato cultivar having a discrete pesticide programme applied to it in one paddock or field. Data from seed potatoes were obtained for seven seasons, 1999-2006, and from process potatoes for four seasons, 2003-2007. Data were entered into a database using SprayView Log (HortPlus) to standardise grower and pesticide names and the amounts of pesticide applied. Cursory summaries of the data were produced using SprayView Analyst (HortPlus), and the data tabulated using Excel. Sequential applications of three or more pesticides from the same chemical class were noted, as this practice has potential to induce resistance in fungal pathogens and insect pests, and in weeds to a lesser extent (Martin et al. 2005). It was assumed that growers used these pesticides to control the appropriate target pests for which individual products are registered for (www.novachem.co.nz).

\section{Seed producers}

\section{RESULTS}

Crop areas averaged 6.3 ha, ranging from 1-20 ha. The pesticides applied to them are listed in Table 1.

There were 17 different fungicide active ingredients (including those in mixes) from 11 fungicide groups applied to potato seed crops during 1999-2006. Pencycuron was the only seed treatment prior to planting, and was used to control black scurf and stem canker (Rhizoctonia solani) in most (over 90\%) of the crops. Most (at least 80\%) of the foliar-applied fungicides were for control of the pathogens causing early and late blight diseases. Mancozeb or mixtures of mancozeb and metalaxyl made up more than half of the fungicide applications to control these two diseases, with the rest being propineb, azoxystrobin, difenoconazole, chlorothalonil, dimethomorph and iprovalicarb/propineb in 2005-2006. Fluazinam was applied in some crops during 2003-2005 to control Sclerotinia sclerotiorum and pathogens causing early and late blight. Dithiocarbamates (mancozeb, propineb) were applied sequentially three or more times on 5-60\% of crops during the survey period; the strobilurin (azoxystrobin) on 11\% of crops in 2001; and triazoles (difenoconazole) on $10 \%$ of crops in 1999 only. Thiabendazole was applied to between 0\% (2005-2006) and 40\% (2002-2004) of harvested tubers to control Fusarium spp., which cause dry rot, and Phoma spp., which cause gangrene, in stored tubers, indicating that its use varied from year to year. 
There were 10 insecticide active ingredients from 5 insecticide groups used against potato tuber moth and/or aphids, along with oils, to prevent transmission of potato viruses. In the six growing seasons, most crops (81-100\%) were sown with seed treated with imidacloprid to provide control of aphids in spring, and the other crops were sown with seed containing no insecticide. Phorate granules were broadcast after planting on one crop in 2004 only, in addition to the imidacloprid seed treatment. The four most commonly used foliar-applied insecticides $(\lambda$-cyhalothrin, methamidophos, pirimicarb and pymetrozine) comprised $97 \%$ of the 856 insecticide applications during the survey period. Mineral oil was applied to foliage at the same time as an insecticide in the majority of crops to disrupt feeding by aphids to limit virus transfer to plants. Three or more sequential applications of organophosphates (mostly methamidophos but also acephate and dimethoate), and occasionally pymetrozine and $\lambda$-cyhalothrin, were applied to $59-100 \%$ crops planted in 1999-2004, but to only 53\% of crops planted in 2005 .

Metribuzin comprised $58-83 \%$ of the eight herbicides alone or in herbicide mixes, comprising 6 chemical classes, that were applied in the seven 1999-2006 growing seasons. Carfentrazone-ethyl was used in the latter years, representing $26 \%$ of herbicides applied in the 2005-06 season. Diquat was used as a desiccant to aid harvesting of the tubers on $56-100 \%$ of crops, on between one to four occasions depending on growing conditions and cultivar.

\section{Process producers}

Crop areas averaged 13.7 ha, ranging from 2-92 ha. The pesticides applied to the crops are listed in Table 2.

The 15 fungicide active ingredients comprised 11 chemical groups. Pencycuron was used as a seed treatment for control of Rhizoctonia solani in all but five crops sown for processing between 2004 and 2007. Control of the pathogens causing early and late blight made up $80-86 \%$ of the total fungicide applications to foliage, mostly with mancozeb and azoxystrobin, which made up 60-80\% of the total applications. Chlorothalonil, copper, propineb, difenoconazole and mancozeb/metalaxyl mixture were used to a lesser extent. Iprovalicarb/propineb was used in the 2005-2006 growing season onwards. Fluazinam was applied in 13-17\% of crops during the survey period to control Sclerotinia sclerotiorum and pathogens causing early and late blight. Chloronitrile (chlorothalonil) was applied sequentially three or more times on 2-20\% of crops during the survey period; dithiocarbamates (mancozeb, propineb) on $90-96 \%$ of crops; pyridinamine (fluazinam) on 7-21\% of crops; strobilurin (azoxystrobin) on 1-4\% of crops; and triazoles (difenoconazole) on 1\% of crops in 2006 only.

Nine insecticide active ingredients from 5 chemical groups were used. Their use differed over the survey period. All potatoes planted in 2003 were treated with imidacloprid seed dressing to control aphids or with phorate in the furrow at planting to control aphids and grass grub, but in subsequent seasons little or no insecticide seed treatment was used. Of the foliar-applied insecticides, pirimicarb and pymetrozine were used for control of aphids more frequently on potatoes planted in 2006 than in previous growing seasons, and $\lambda$-cyhalothrin was used for aphid and/or potato tuber moth control consistently throughout the survey period in $12-20 \%$ of crops per season. Three sequential applications of pyrethroids were applied to 2\% of crops in 2003-2004 season, and organophosphates to $1 \%$ of crops and carbamates to $2 \%$ of crops in the 2004-2005 season, with none in subsequent seasons.

Cyanazine, glyphosate, linuron and metribuzin comprised $86-95 \%$ of the 15 herbicides alone or in herbicide mixes applied in the four 2003-2007 growing seasons. Diquat was used as a desiccant to aid harvesting of the tubers on $18-46 \%$ of crops, usually once and rarely twice in a season. The common pre-emergence or emergence residual herbicides (cyanazine, linuron and metribuzin) were used for weed control in crop establishment in accordance with accepted agricultural practice. 


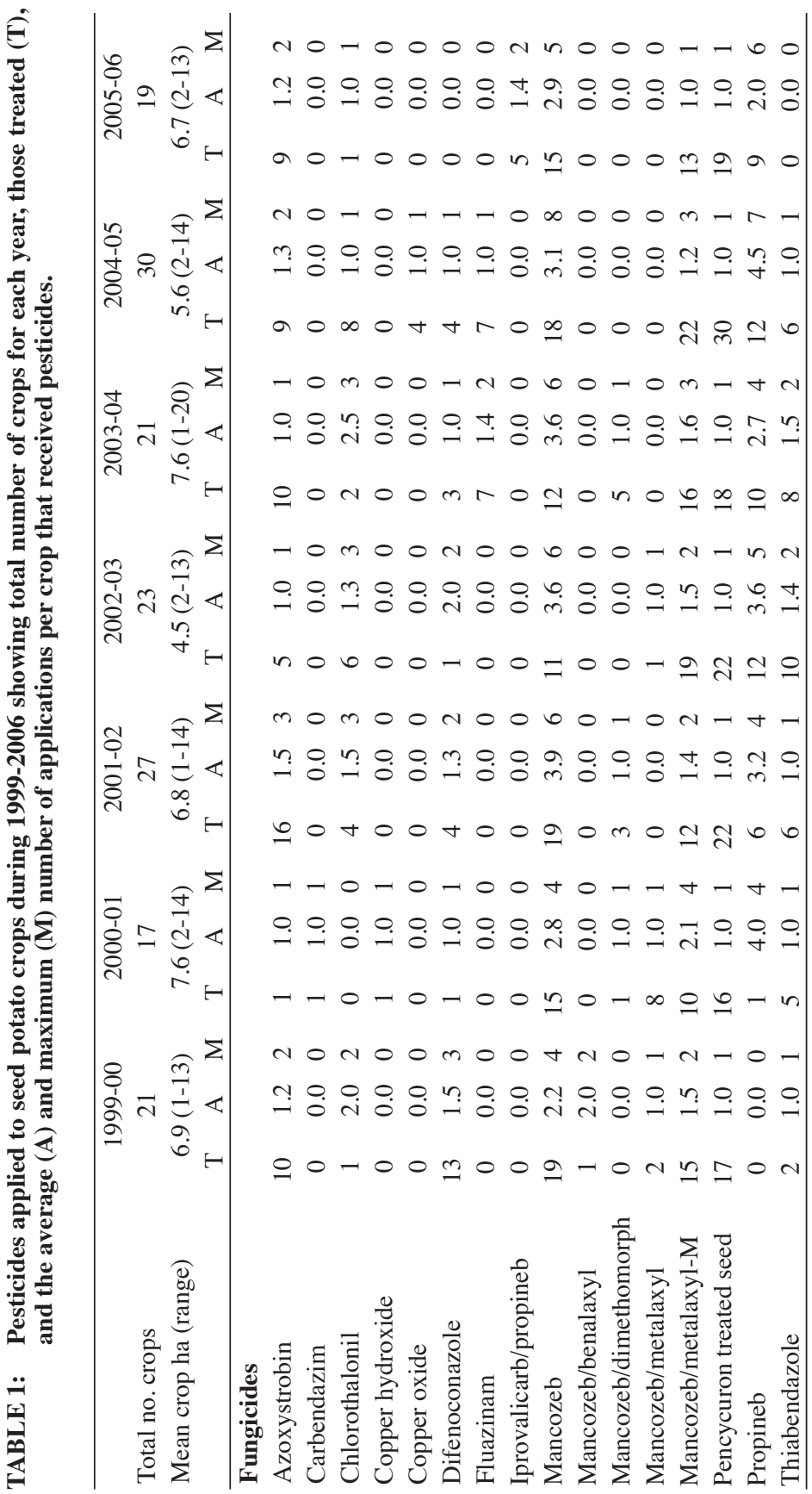




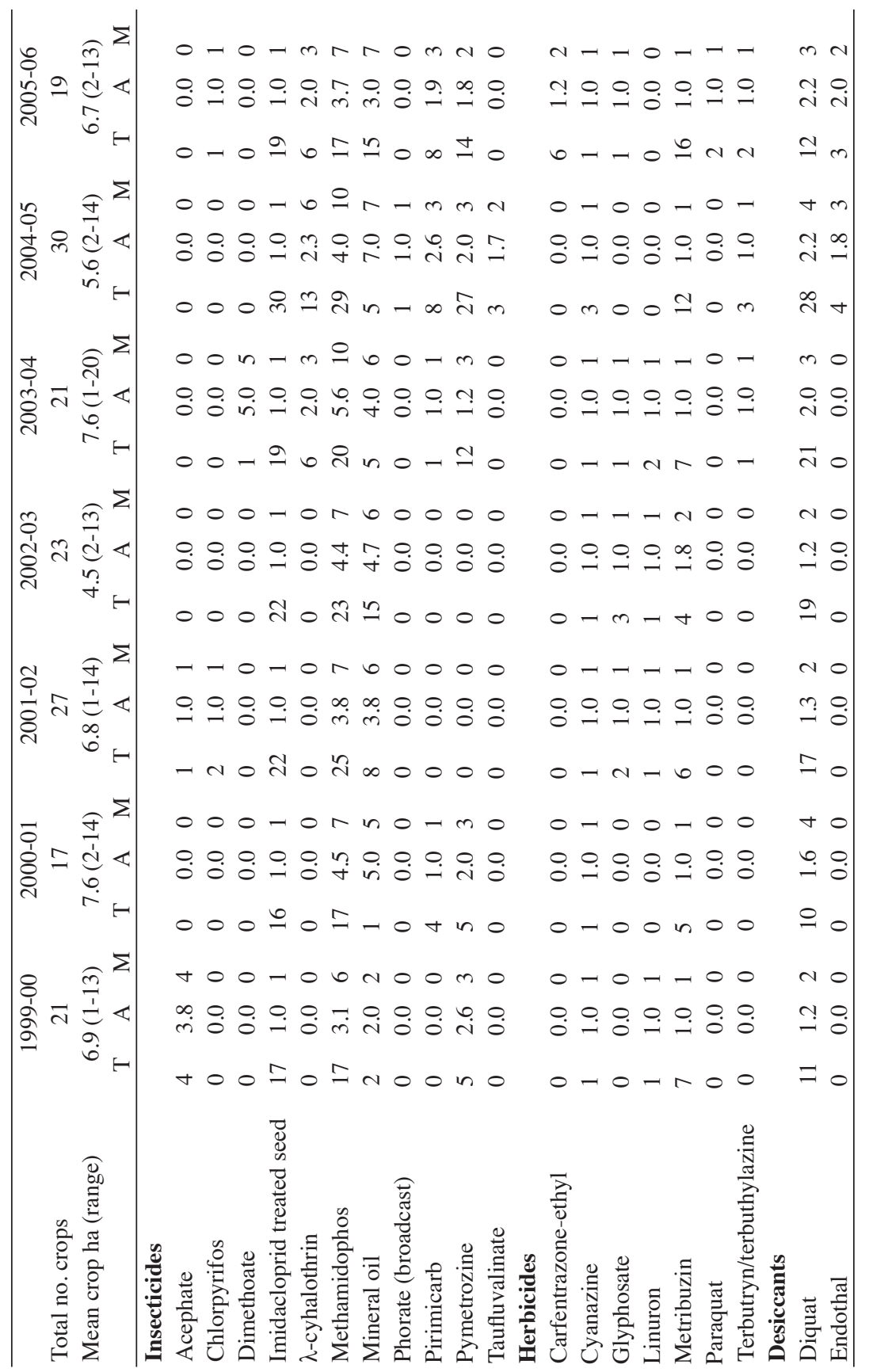




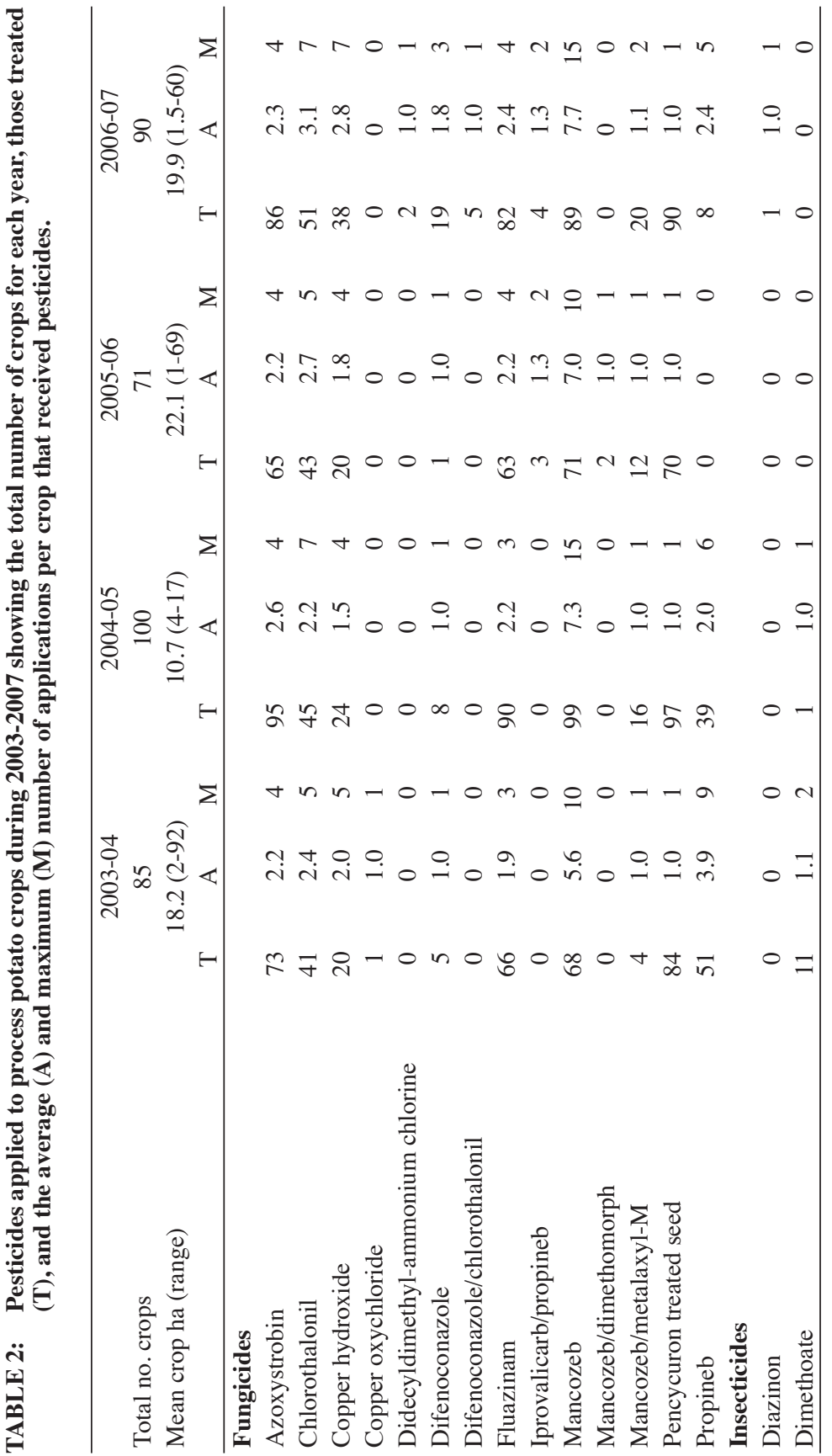




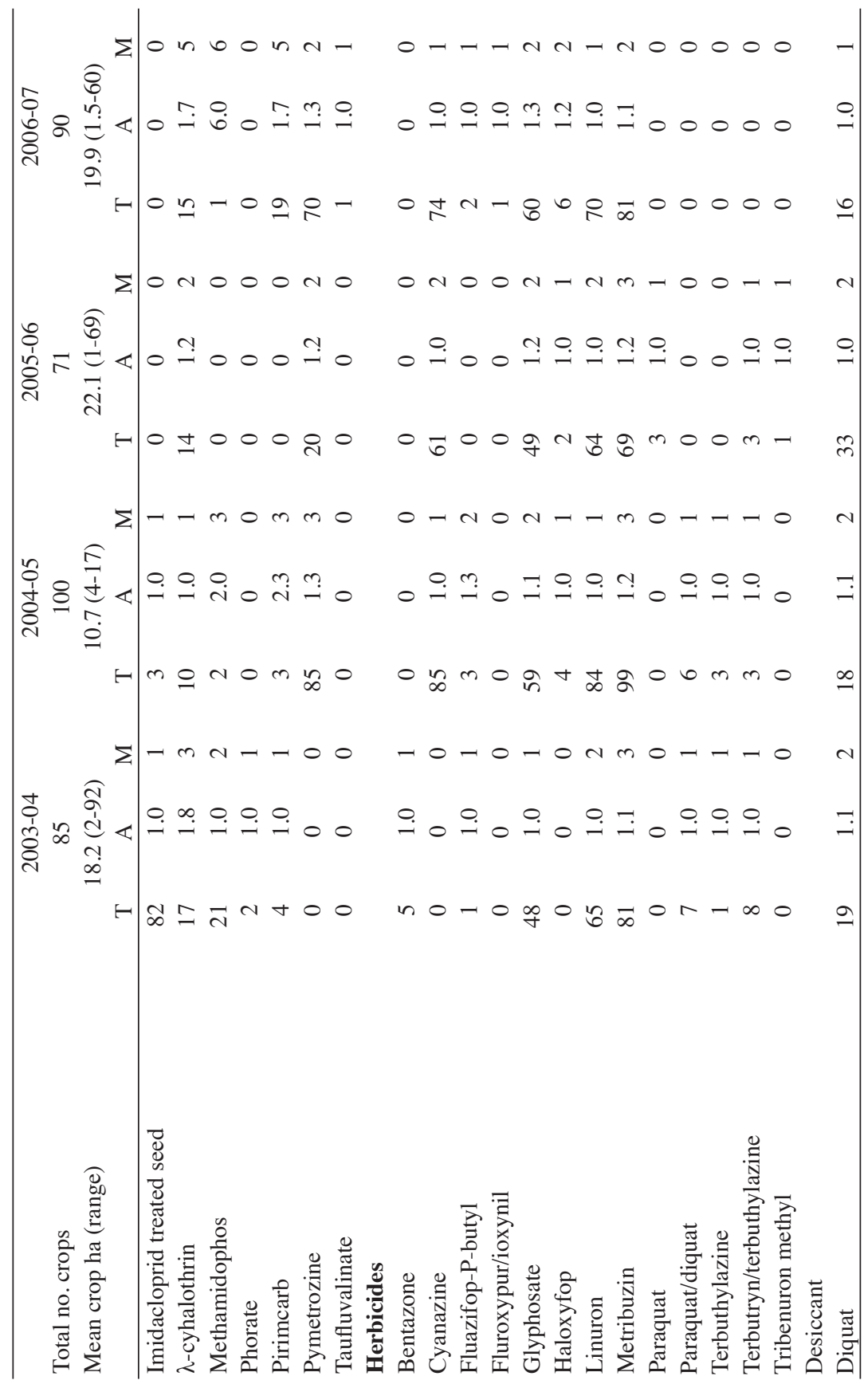




\section{DISCUSSION}

Spray diaries from potato growers in Canterbury in the past 4-7 years showed the pesticides used over an average of $157 \mathrm{ha} /$ year of seed potatoes for propagation by process producers, and $1679 \mathrm{ha} /$ year of process potatoes. Overall, there were approximately 1200 ha of certified seed potatoes and 5900 ha of certified process potatoes grown per year in New Zealand during the survey period (R. Gall, pers. comm.). Most of the remaining area grown for seed, about 1050 ha certified and about 200 ha not certified, is grown from whole seed for the fresh varietal market, and since pesticide diaries were generally not kept by growers for this potato segment, their pesticide use is not recorded (K. Hughes, pers. comm.). However, since whole-seed crops mature more quickly than cut-seed crops, the foliage would be expected to receive significantly less pesticide than that for crops grown from cut seed.

More than $90 \%$ of both seed and process crops received a seed treatment to control Rhizoctonia solani prior to planting. Process crops received more fungicides than seed crops, with some crops from both markets receiving three or more sequential applications of fungicides from chloro-nitrile (chlorothalonil,) dithiocarbamate (mancozeb), pyridinamine (fluazinam), strobilurin (azoxystrobin) and triazole (difenoconazole) chemical groups (Appendix I). Fungicide resistance recommendations for the number of fungicides applied sequentially in a potato growing season vary depending on the chemical group (Martin et al. 2005). In a season, no more than four applications of morpholine (dimethomorph) fungicides should be applied per crop. For DMI fungicides (difenoconazole, thiabendazole) and phenylamides (metalaxyl-M), a maximum of three applications per crop is advised. Alternaria solani isolates resistant to strobilurin fungicides have already appeared in the USA (Rosenzweig et al. 2008), and strobilurins should make up no more than one-third of the total fungicides applied to each crop (Martin et al.2005). These recommendations were generally adhered to by growers. The repeated applications of dithiocarbamates used by the growers, though, have not resulted in fungal pathogens resistant to this chemical class, although variation in sensitivity to mancozeb has been reported in P. infestans populations in the USA (Daayf \& Platt 2002).

Over the survey period, most seed crops received a single seed treatment (imidacloprid) as well as 1-12 (but averaging 5.5) foliar applications of insecticides from four insecticide classes. Prior to the 2005-2006 growing season, most crops received more than three sequential applications of organophosphates. This finding matches that reported previously (van Toor \& Teulon 2006). This practice may have selected for aphids resistant to insecticides from this and other chemical classes, as shown by van Toor et al. (2008) who found that 22 of 45 M.persicae aphids collected on potatoes in autumn 2005, within the regions where the crops were grown, carried multiple copies of genes producing high levels of carboxylesterase that conferred resistance to organophosphate, carbamate and pyrethroid insecticides. However, the practice of three or more sequential applications of methamidophos declined somewhat in the 2005-2006 season, coinciding with the release of Sustainable Farming Fund (SFF) potato aphid virus report on insecticide management in which alternating insecticides from different chemical classes were recommended (van Toor \& Teulon 2005). This change in insecticide practice highlights the benefits of the SFF in modifying previous practices towards more sustainable insecticide use. Process crops were also mostly seed treated in 2003, but not in subsequent years, and had considerably fewer foliar applications of insecticides (usually 1-2 but occasionally up to 6 ) than seed crops. This study has benchmarked insecticide use patterns before the predicted incursion into Canterbury of the potato psyllid (Bactericera cockerelli).

\section{ACKNOWLEDGEMENTS}

We thank all the potato growers who supplied information on pesticide usage; Ron Gall of Horticulture New Zealand supplied information on crops sown; John Jackson and Christine Clouston of McCain Foods, and Kerry Hughes of Alex McDonald Merchants for supplying spray diaries; HortPlus for supplying the software package SprayView Analyst and validating the database; the New Zealand Foundation for Research, Science and Technology for funding; Crop \& Food staff members, Yvonne Botha, for data entry of many spray diaries, and John Anderson, on aspects of potato production. 


\section{REFERENCES}

Anon. 2008. New Zealand Novachem Agrichemical Manual. AgriMedia Ltd, Ashcroft House, Christchurch, New Zealand.

Cameron PJ, Walker GP 1988. Insecticide resistance in green peach aphid from South Auckland. Proceedings of the 41st New Zealand Weed and Pest Control Conference. Pp. 85-89.

Daayf F, Platt HW 2002. Variability in responses of US-8 and US-11 genotypes of potato and tomato isolates of Phytophthora infestans to commercial fungicides in vitro. American Journal of Potato Research 79: 433-441.

Fellowes RW, Fergusson AM 1994. Field evidence for resistance to certain insecticides to green peach-potato aphid in South Auckland. New Zealand Journal of Experimental Agriculture 2: 83-88.

Hartill WFT, Tompkins GR, Kleinsman PJ 1983. Development in New Zealand of resistance to dicarboximide fungicides in Botrytis cinerea, and to acylalanines in Phytophthora infestans, and to guazatine in Penicillium italicum. New Zealand Journal of Agricultural Research 26: 261-269.

Lehtinen A, Hannukkala A, Andersson B, Hermansen A, Le VH, Naerstad R, Brurberg MB, Nielsen BJ, Hansen JG, Yuen J 2008. Phenotypic variation in Nordic populations of Phytophthora infestans in 2003. Plant Pathology 57(2): 227-234.

Manktelow D, Stevens P, Walker J, Gurnsey S, Park N, Zabkiewicz J, Teulon D, Rahman A 2005. Trends in Pesticide Use in New Zealand: 2004. In: Report to the Ministry for the Environment, Project SMF4193. HortResearch, Palmerston North, New Zealand.

Martin NA, Beresford RM, Harrington KC ed. 2005. Pesticide Resistance: Prevention and Management Strategies 2005. New Zealand Plant Protection Society, Hastings, New Zealand. 166 pp.

Martin NA, Workman PJ 1997. Melon aphid (Aphis gossypii) resistance to pesticides. Proceedings of the 50th New Zealand Plant Protection Conference. Pp. 405-408.

Rosenzweig N, Atallah ZK, Olaya G, Stevenson WR 2008. Evaluation of QoI fungicide application strategies for managing fungicide resistance and potato early blight epidemics in Wisconsin. Plant Disease 92(4): 561-568.

Stufkens MAW, Teulon DAJ 2001. Aphid species on potato crops in Canterbury. New Zealand Plant Protection 54: 235-239.

van Toor RF, Foster SP, Anstead JA, Mitchinson S, Fenton B, Kasprowicz L 2008. Insecticide resistance and genetic composition of Myzus persicae (Hemiptera: Aphididae) on field potatoes in New Zealand. Crop Protection 27: 236-247.

van Toor RF, Teulon DAJ 2005. Potato aphid virus project - Final report 2002-05 Towards an insecticide resistance management strategy to control aphid virus vectors in potatoes. Confidential Client Report for MAF Sustainable Farming Fund No. 1509. Crop \& Food Research, Lincoln, New Zealand. 66 pp.

van Toor RF, Teulon DAJ 2006. Insecticide practice for aphid control in potatoes. New Zealand Plant Protection 59: 235-241. 
APPENDIX I: Number of applications per crop of the agrichemical active ingredients within their FAO chemical grouping. Data are presented for (a) seed and (b) process crops.
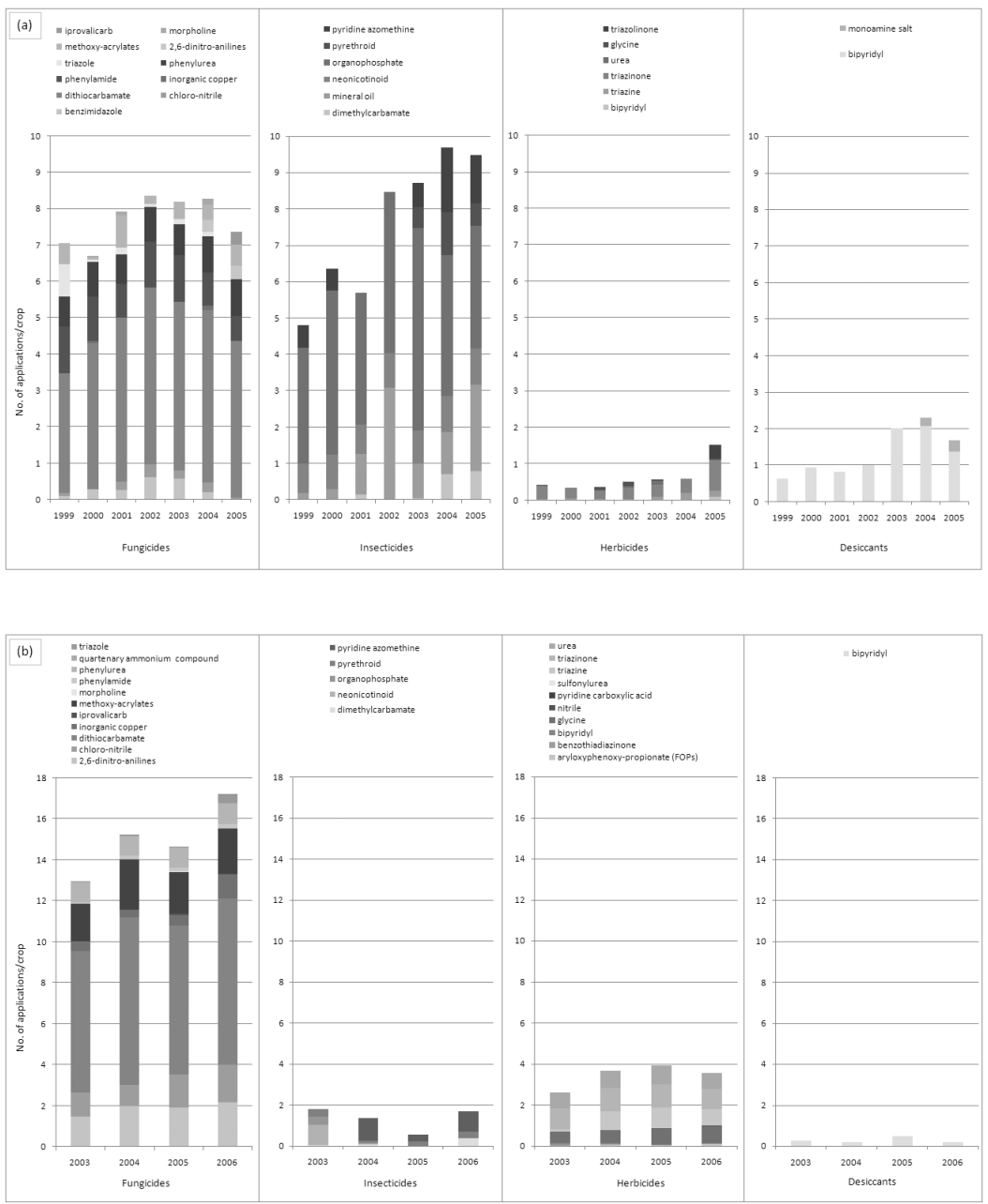